\title{
Lipomatous Hamartoma
}

National Cancer Institute

\section{Source}

National Cancer Institute. Lipomatous Hamartoma. NCI Thesaurus. Code C40426.

A benign hamartomatous lesion composed predominantly of adipose tissue. 